\title{
BAB II
}

\section{TINJAUAN PUSTAKA}

\subsection{Penelitian Terdahulu}

Pada penelitian yang telah dilakukan sebelumnya, metode yang digunakan berupa K-Means, Elbow, dan RFM, dapat di lihat pada Tabel 2.1. Telah diterapkan metode-metode dalam menyelesaikan kasus terkait dengan segmentasi pelanggan. Perbedaan dari keseluruhan penelitian tersebut berada pada metode yang diterapkan sebagai dasar perbandingan mencari hasil yang terbaik ataupun gabungan dalam melakukan penelitiannya. Pada penelitian ini penulis berencana untuk menggabungkan metode K-Means(Euclidean \& Manhattan), Elbow, Silhoutte Coefficient dan $R F M$ dalam membuat segmentasi pelanggan dari studi kasus pada PT Hasjrat Abadi Ambon.

Tabel 2. 1. Penelitian Sebelumnya

\begin{tabular}{|c|c|c|c|}
\hline Penulis & Judul & $1 / 71$ & Hasil Penelitian \\
\hline $\begin{array}{l}\text { Mediana } \\
\text { Aryuni, } \\
\text { dan } \\
\text { kawan- } \\
\text { kawan }\end{array}$ & $\begin{array}{l}\text { Costumer Segmentation } \\
\text { XYZ Bank using K- } \\
\text { Means and K-Medoids" } \\
\text { Clustering [7] }\end{array}$ & $\begin{array}{l}\text { 2. K-Medoids } \\
\text { 3. RFM }\end{array}$ & $\begin{array}{l}\text { Metode } K \text {-Means lebih } \\
\text { unggul dari K-Medoids } \\
\text { dari hasil evaluasi } \\
\text { menggunakan metode } \\
D B I\end{array}$ \\
\hline $\begin{array}{c}\text { Ina } \\
\text { Maryani, } \\
\text { dan } \\
\text { kawan- } \\
\text { kawan }\end{array}$ & $\begin{array}{l}\text { Customer Segmentation } \\
\text { based on RFM model } \\
\text { and Clustering } \\
\text { Techiques With } K \text { - } \\
\text { Means Algorithm [1] }\end{array}$ & $\begin{array}{l}\text { 1. K-Means } \\
\text { 2. RFM }\end{array}$ & $\begin{array}{l}\text { Dengan menerapkan } \\
\text { Metode } R F M \text { dan } K \text { - } \\
\text { Means maka } \\
\text { memperoleh } 2 \text { Cluster } \\
\text { dari hasil analisa } R F M \\
\text { yang akan di pakai } \\
\text { untuk pertimbangan } \\
\text { perusahaan }\end{array}$ \\
\hline $\begin{array}{l}\text { A. Joy } \\
\text { Christy, } \\
\text { dan }\end{array}$ & $\begin{array}{l}R F M \text { ranking }-\mathrm{An} \\
\text { Effective approach to } \\
\text { customer segmentation }\end{array}$ & $\begin{array}{ll}\text { 1. } & \text { K-Means } \\
\text { 2. } & \text { RM K- } \\
& \text { Means }\end{array}$ & $\begin{array}{cr}\text { 1. Metode } & K \text {-Means } \\
\text { diketahui } & \text { lebih } \\
\text { unggul } & \text { dalam }\end{array}$ \\
\hline
\end{tabular}




\begin{tabular}{|c|c|c|c|}
\hline $\begin{array}{l}\text { kawan- } \\
\text { kawan }\end{array}$ & [3] & $\begin{array}{ll}\text { 3. } & \text { Fuzzy C- } \\
& \text { Means } \\
\text { 4. } & \text { RFM }\end{array}$ & $\begin{array}{l}\text { kecepatan mengolah } \\
\text { data dan lebih } \\
\text { sedikit jumlah iterasi } \\
\text { 2. } R F M \text { merupakan } \\
\text { model yang baik } \\
\text { dalam membuat } \\
\text { strategi marketing }\end{array}$ \\
\hline $\begin{array}{l}\text { Morteza } \\
\text { Namvar } \\
\text {, dan } \\
\text { kawan- } \\
\text { kawan }\end{array}$ & $\begin{array}{l}\text { A Two Phase Clustering } \\
\text { Method for Intelligent } \\
\text { Customer Segmentation } \\
\text { [4] }\end{array}$ & $\begin{array}{ll}\text { 1. } & \text { K-Means } \\
\text { Neural } \\
\text { network } \\
\text { classificat }\end{array}$ & $\begin{array}{l}\text { Dalam memperoleh } \\
\text { strategi marketing } \\
\text { yang lebih perinci } \\
\text { maka dilibatkan data } \\
\text { demografi pelanggan } \\
\text { dalam menentukan } \\
\text { keputusan ke } \\
\text { pelanggan }\end{array}$ \\
\hline $\begin{array}{l}\text { Marutho, } \\
\text { dan } \\
\text { kawan- } \\
\text { kawan }\end{array}$ & $\begin{array}{l}\text { The Determination of } \\
\text { Cluster Number at k- } \\
\text { mean using Elbow } \\
\text { Method and Purity } \\
\text { Evaluation on Headline } \\
\text { News [5] }\end{array}$ & $\frac{2}{2}$ & $\begin{array}{l}\text { Penerapan Metode } K \text { - } \\
\text { Means yang di } \\
\text { perpadukan dengan } \\
\text { Elbow memberikan } \\
\text { nilai Cluster yang } \\
\text { terbaik untuk } \\
\text { mengelompokkan } \\
\text { data yang bersamaan } \\
\text { di uji dengan Purity }\end{array}$ \\
\hline
\end{tabular}

Pada Tabel 2.1. Menjelaskan perbandingan dari beberapa jurnal sebelumnya yang menggunakan berbagai metode dalam menyelesaikan masalah pengelompokan data menggunakan metode Clustering. Pada beberapa jurnal tersebut ada yang menjelaskan bagaimana perbandingan dari beberapa metode Clustering, berupa $K$ Means, K-Medoids, RM K-Means, Fuzzy C-Means dan Neural Network Classification. Hasil yang diberikan dari beberapa metode tersebut menjelaskan bagaimana metode $K$-Means lebih unggul dalam mengelompokkan data, khususnya pada penelitian yang berkait pada segmentasi pelanggan. Beberapa jurnal juga 
menjelaskan bagaimana $R F M$ merupakan model yang baik dalam melakukan segmentasi pelanggan untuk strategi marketing. $R F M$ juga sering diperpadukan dengan metode $K$-Means dalam berbagai penelitian. Metode Elbow pada penelitian sebelumnya menyimpulkan bahwa, nilai Cluster yang dicari dalam melakukan analisa dengan metode $K$-Means memiliki hasil yang baik dan akurat, terlebihnya berdasarkan bukti bahwa hasil penentuan nilai Cluster dari metode Elbow sama dengan hasil terbaik dari evaluasi purity internal.

\subsection{Segmentasi Pelanggan}

Segmentasi pelanggan merupakan pembentukan kelompok data baru yang berfungsi dalam penilaian loyalitas suatu pelanggan pada perusahaan. Variabel yang dapat dinilai dari perusahaan merupakan variabel penting dari data suatu pelanggan. Data yang dinilai dapat berupa jejak transaksi pelanggan pada perusahaan, rentan waktu sering mengunjungi perusahaan dalam memperoleh nilai loyalitas pelanggan, ada juga frekuensi kedatangan pelanggan, yang bertujuan dalam mengetahui sesering apakah seorang pelanggan sering berkunjung, dan pastinya sebesar apakah seorang pelanggan melakukan transaksi [8]. Pada segmentasi pelanggan terdiri dari berbagai jenis, yaitu berupa [10]:

\subsubsection{Segmentasi Pelanggan - Geographic}

Segmentasi ini memiliki fokus untuk membagi/pelanggan-pelanggan berdasarkan faktor lokasi. Lokasi yang dituju dapat berupa negara, benua, kota, ataupun yang paling detail yaitu perumahan. Tujuan dari segmentasi ini yaitu membedakan tindakan yang akan di berikan oleh perusahaan berdasarkan lokasi. Contoh dari tujuan segmentasi pelanggan geographics yaitu, bagaimana perusahaan dapat membedakan kebutuhan berdasarkan lokasi, pada benua Asia lebih banyak mengonsumsi beras dari pada gandum yang berada di benua Eropa. Maka dari hasil segmentasi ini dapat memberikan kemudahan pada perusahaan untuk menentukan sistem marketing.

\subsubsection{Segmentasi Pelanggan - Demographic}

Segmentasi Demographic memiliki fokus dalam biodata seorang pelanggan. Data yang dapat diperoleh pada Demographic berupa usia, jenis kelamin, agama, edukasi, dan penghasilan. Berdasarkan data Demographic dapat memberikan keuntungan pada perusahaan dalam 
menentukan pilihan-pilihan seperti,
a. Pelanggan dengan rentan usia yang di tentukan
b. Jenis kelamin yang ditarget
c. Edukasi dari pelanggan
d. D11

Fungsi dari segmentasi ini dapat memberikan keuntungan pada perusahaan untuk memberikan keputusan kepada pelanggan berdasarkan salah satu data Demographic ataupun beberapa data. Contoh segmentasi yang di tentukan berdasarkan data pelanggan yaitu, perusahaan dapat mengetahui pelanggan dengan rentan umur $12-23$ dan berstatus mahasiswa/siswa lebih meminati produk A dibanding produk B.

\subsubsection{Segmentasi Pelanggan - Behavioral}

Segmentasi ini berdasarkan dari keputusan yang di ambil oleh pelanggan, seperti halnya lifestyle ataupun kebiasaan berbelanja. Pada segmentasi ini memiliki fungsi dalam memberikan keputusan pada perusahaan berdasarkan data behavioral tiap-tiap pelanggan. Contohnya pelanggan yang mendatangi mal pembelanjaan lebih sering melakukan pembelanjaan yang besar pada awal bulan, contoh lainya yaitu pelanggan yang membeli susu juga sering membeli roti. Segmentasi tersebut dapat terjadi berdasarkan riwayat dari pelanggan, bagaimana kebiasaan mereka dalam berbelanja.

\subsubsection{Segmentasi Pelanggan - Firmographic}

Segmentasi ini memiliki kemiripan dengan segmentasi Demographics yang mengambil data berdasarkan biodata individu akan tetapi segmentasi firmographics lebih berfokus pada sekelompok organisasi. Fungsi dari segmentasi ini yaitu dapat memberikan perusahaan untuk mempertimbangkan aspek berhubungan dari sebuah industri, seperti halnya dari aspek industri, yaitu ukuran perusahaan atau kekuatan pekerja. 


\subsubsection{Segmentasi Pelanggan - Psychographic}

Segmentasi Psychographic merupakan segmentasi yang memiliki titik fokus pada psikologis pelanggan dan perilakunya. Dalam membagi pelanggan pada segmentasi ini, faktor yang diutamakan yaitu nilainilai dari gaya hidup dan kepentingan dari faktor-faktor lain. Contoh dari segmentasi ini yaitu pada rumah sakit atau apotek, di mana pelanggan dibagi menjadi beberapa kelompok sesuai dengan gaya hidup mereka dan obat yang ditargetkan sesuai untuk dikonsumsi pada tiap pelanggan, atau contoh lainnya yaitu dosis obat yang boleh di gunakan oleh beberapa pelanggan yang memiliki efek samping pada obat-obatan tertentu.

\subsubsection{Segmentasi Pelanggan - Smart}

Segmentasi ini merupakan tipe yang baru dikarenakan penentuan perusahaan ke pelanggan tidak hanya dari satu jenis segmentasi, akan tetapi gabungan dari beberapa segmentasi untuk menghasilkan penentuan yang bervarian. Eungsi dari segmentasi ini untuk menentukan berbagai pilihan dalam mencari solusi yang detail untuk di selesaikan. Contoh dari segmentasi smart ini seperti, menentukan mahasiswa yang tepat untuk diberikan beasiswa, di mana mahasiswa yang tepat untuk mendapatkannya memiliki/data demografik yang menandakan bahwa mahasiswa tersebut memiliki pemasukan tiab bulan di bawah 1 juta, dan data behavioral menandakan bahwa dia rajin kuliah dan memiliki nilai yang baik, juga berdasarkan data geografiknya yang menandakan bahwa mahasiswa tersebut berasal dari luar kota malang maka akan mendapatkan 30\% tambahan beasiswa kepadaannya.

\subsection{Recency, Frequency, Monetary (RFM)}

Metode RFM atau Recency, Frequency, dan Monetary, metode ini merupakan metode yang dapat mengelompokkan pelanggan berdasarkan nilai skornya. Nilai skor yang diberikan kepada pelanggan memiliki fungsi dalam penilaian dari perusahaan untuk memberikan keputusan kepada pelanggan, hal tersebut dapat berupa pemberian discount, give away, dll. Skor pelanggan yang diperoleh dengan metode $R F M$ berasal dari catatan transaksi pelanggan pada perusahaan. 


\subsubsection{Recency}

merupakan nilai dari jarak waktu kedatangan terakhir sampai berakhirnya pendataan. Tinggi dan kecilnya nilai akan menjadi patokan seberapa seringkah pelanggan melakukan transaksi pada perusahaan. Nilai yang kecil memberi arti berupa, pelanggan lebih tertarik untuk melakukan transaksi yang sering pada perusahaan. Nilai yang besar menandakan pelanggan tidak berminat untuk sering berkunjung.

\subsubsection{Frequency}

merupakan nilai dari jumlah seberapa banyakkah pelanggan melakukan pembelian atau berkunjung. Nilai Frequency diartikan sebagai jumlah pembelian yang dilakukan pelanggan dalam jangka waktu tertentu. Besarnya nilai Frequency bertanda tingginya loyalitas seorang pelanggan.

\subsubsection{Monetary}

merupakan nilai dari seberapa banyakkah pelanggan bertransaksi di perusahaan. Semakin besar nilai Monetary maka semakin besar pendapatan perusahaan yang di berikan oleh pelanggan.

Penetapan nilai $R F M$ pada setiap pelanggan memiliki nilai yang berbeda beda. Pemberian skala dari skor 5 sampai 1. Nilai skor tertinggi yang dapat di berikan berupa angka 5 sampai yang terkecil yaitu 1 (ataupun sebaliknya), pada tiap skor yang diberikan memiliki karakter unik tersendiri. Dari penetapan skor yang telah ditentukan maka pelanggan yang memiliki tingkat loyalitas tinggi dalam memberikan profit dapat di tandai dengan skor $R F M$ berupa ketiga nilai terbaiknya 111. Pemberian skor dari ke variabel dimensi tadi dapat diberikan ke pelanggan antara skor 555,554,553 ... 113,112,111 [3]. 
Tabel 2.2. Deskripsi Skor $R F M$

\begin{tabular}{|c|l|l|}
\hline Skor & \multicolumn{1}{|c|}{ Karakteristik } & \multicolumn{1}{c|}{ Status } \\
\hline 5 & Berpotensi & Titanium \\
\hline 4 & Menjanjikan & Diamond \\
\hline 3 & Tidak bisa kehilangan mereka & Gold \\
\hline 2 & Dalam Risiko & Silver \\
\hline 1 & Kehilangan & Bronze \\
\hline
\end{tabular}

\subsubsection{Cara Kerja Model RFM}

Data yang ada akan dipilih (data selection) sebagai variabel yang akan ditentukan sebagai skor RFM. Data yang telah dipilih akan dikelompokkan menjadi Recenecy, Frequency, dan Monetary berdasarkan rate yang ditentukan. Rate yang ditentukan dapat ditentukan dalam bentuk persen $(25 \%, 50 \%, 75 \%, 100 \%)$ ataupun sesuai dari pilihan data yang ada. Berikut contoh bagaimana model RFM di terapkan [11].

a. Contoh Dataset yang telah dipilih

Tabel 2.3. Tabel Dataset

\begin{tabular}{|l|l|l|l|}
\hline ID_Pelanggan & Benda & Tanggal & Harga \\
\hline 00001 & Laptop Asus A & $19-04-2019$ & Rp.12.000.000 \\
\hline 00002 & Laptop Acer A & $28-04-2019$ & Rp.11.000.000 \\
\hline 00002 & Laptop Acer B & $02-05-2019$ & Rp.15.000.000 \\
\hline 00001 & Laptop Asus A & $05-05-2019$ & Rp.12.000.000 \\
\hline 00001 & Laptop Asus B & $05-05-2019$ & Rp.22.000.000 \\
\hline 00003 & Laptop MSI A & $01-06-2019$ & Rp.20.000.000 \\
\hline
\end{tabular}

Pada data di atas merupakan contoh dataset dari transaksi pelanggan pada perusahaan Laptop. Variabel yang dipilih berupa dari ID_Pelanggan, Benda, Tanggal, dan Harga. Data yang telah dipilah akan menjadi patokan dalam pembentukan Model RFM. 
b. Di buatkan sortir pada dataset.

Tabel 2.4. Tabel Sortir Data

\begin{tabular}{|c|c|l|l|}
\hline Skor & Rating R & Rating F & Rating M \\
\hline 1 & $1-20$ Hari & $>=100 \mathrm{x}$ & $>=\mathrm{Rp} .100 .000 .001$ \\
\hline 2 & $21-40$ Hari & $26-100 \mathrm{x}$ & $\begin{array}{l}\text { Rp.42.000.001- } \\
\text { Rp.100.000.000 }\end{array}$ \\
\hline 3 & $41-60$ Hari & $11-25 \mathrm{x}$ & $\begin{array}{l}\text { Rp.22.000.001- } \\
\text { Rp.42.000.000 }\end{array}$ \\
\hline 4 & $61-120$ Hari & $3-10 \mathrm{x}$ & $\begin{array}{l}\text { Rp.12.000.001- } \\
\text { Rp.22.000.000 }\end{array}$ \\
\hline 5 & $>=121$ Hari & $1-2 \mathrm{x}$ & $\mathrm{Rp} .1-\mathrm{Rp} .12 .000 .000$ \\
\hline
\end{tabular}

Berdasarkan tabel di atas maka dapat dibuatkan data baru berdasarkan sortir yang telah ditentukan, untuk nilai rating dapat ditentukan berdasarkan rata-rata nilai tiap variabel atau menggunakan satuan persen seperti yang telah dijelaskan sebelumnya. Pada contoh ini, skor yang tergolong terbaik bermulai dari nilai 1 sampai 5, rating $\mathrm{R}$ memiliki nilai dari jarak waktu kedatangan terakhir pelanggan ke perusahaan sampai dini hari, rating $\mathrm{F}$ memiliki nilai dari Berapa kali pelanggan berkunjung ke perusahaan, dan rating $\mathrm{M}$ memiliki nilai dari seberapa banyak pelanggan bertransaksi pada perusahaan.

c. Data pelanggan di sortir dan dibuatkan data baru (Model $R F M$ ), untuk penilaian nilai Recency maka set tanggal sekarang menjadi 01-01-2020 sebagai contoh dan dihitung jarak kurun waktu dari terakhir berkunjung sampai waktu sekarang, berikut merupakan perhitungannya.

1. Tahap Sortir Nilai Recency

ID_Pelanggan $=00001$

Nilai R = Jangka Waktu Kedatangan 


$$
\begin{aligned}
& =05-05-2019-01-01-2020 \\
& =241 \text { Hari }
\end{aligned}
$$

2. Tahapan Sortir Nilai Frequency

ID_Pelanggan $=00001$

Nilai $\mathrm{F} \quad=$ Total Kedatangan

$=19-04-2019+05-05-2019+05-05-2019$

$=3$ kali

3. Tahapan Sortir Nilai Monetary

$$
\text { ID_Pelanggan }=00001
$$

Nilai $\mathrm{M}=$ Total Transaksi

$$
=12.000 .000+12.000 .000+22.000 .000
$$

$$
=46.000 .000
$$

4. Ketiga tahapan tersebut diulangi pada keseluruhan data pelanggan sebelum berlanjut pada scoring.

Tabel 2.5. Tabel Hasil Sortir RFM

\begin{tabular}{|l|l|l|l|}
\hline ID_Pelanggan & Nilai R & Nilai F & Nilai M \\
\hline 00001 & 241 Hari & 3 Kali & 46.000 .000 \\
\hline 00002 & 244 Hari & 2 Kali & 26.000 .000 \\
\hline 00003 & 214 Hari & 1 Kali & 20.000 .000 \\
\hline
\end{tabular}

d. Scoring Dataset yang telah disortir

1. Tahapan Scor Nilai Recency
ID_Pelanggan
$=00001$
Nilai R
$=241$ Hari
Tabel Scor R
$=(>=121$ Hari $)$
Skor R Pelanggan
$=5$ 
2. Tahapan Skor Nilai Frequency
ID_Pelanggan
$=00001$
Nilai F
$=3$ Kali
Tabel Scor F
$=(3-10)$
Skor F Pelanggan
$=4$

3. Tahapan Skor Nilai Monetary

ID_Pelanggan $\quad=00001$

Nilai M

$=46.000 .000$

Tabel Scor M $=(42.000 .001-100.000 .000)$

Skor $M$ Pelanggan

4. Lakukan ketiga tahapan yang sama pada tiap data pelanggan yang lain.

Tabel 2.6. Tabel Hasil Pemodelan RFM

\begin{tabular}{|l|l|l|l|l|l|}
\hline ID_Pelanggan & R & F & M & RFM SCORE & Status \\
\hline 00001 & 5 & 4 & 2 & 542 & Gold \\
\hline 00002 & 5 & 5 & 3 & 553 & Silver \\
\hline 00003 & 5 & 5 & 3 & 553 & Silver \\
\hline
\end{tabular}

Data pelanggan yang telah di segmentasikan menggunakan model $R F M$ memberikan hasil seperti tabel di atas, setelah RFM SCORE telah diperoleh, maka dapat diterapkan Status baru kepada pelanggan. Status menandakan tingkat loyalitas seseorang pelanggan, pada contoh ini menggunakan julukan Diamond, Gold, Silver, dll hal ini untuk memudahkan pihak perusahaan untuk mengetahui status baru dari pelanggan berdasarkan rekapan datadatanya. Dengan menggunakan status baru pada pelanggan maka perusahaan dapat memberikan tindakan/treat yang sesuai kepada pelanggan untuk meningkatkan tingkat loyalitasnya. 


\subsection{Elbow}

Merupakan metode yang sering digunakan sebagai pengoptimalan nilai $\mathrm{K}$ pada metode K-Means. Nilai K atau nilai dari banyaknya Cluster yang akan ditentukan dalam pengelompokan data melalui hasil dari Cluster K-Means.

\subsubsection{Cara Kerja Metode Elbow}

Dalam menentukan nilai K yang sesuai, maka metode Elbow memiliki cara dengan menghitung nilai Sum Square Error (SSE) pada tiap-tiap nilai Cluster. Nilai Cluster yang dipilih akan menampilkan grafik dari penurunan nilai, nilai yang turun secara drastis dan membentuk lekukan akan dinyatakan sebagai nilai K yang sesuai [12].

Tahapan pertama yaitu ditentukan nilai $\mathrm{K}$ yang akan digunakan sebagai jumlah Cluster untuk dibentuk menggunakan SSE

$$
S S E=\sum_{i=1}^{k} \sum_{x j \in S i}\|X j-\mu i\|^{2}
$$

Keterangan:

Pj = Dataset pada Cluster Si (Cluster 1/Cluster 2/ ... Cluster n)

$\mu i \quad=$ Centroid dari Cluster atau nilai mean dari total dataset Cluster

Perhitungan :

Berikut merupakan contoh dari perhitungan metode Elbow pada Cluster $=1-5$

a. Cluster 1

Dataset $=$

\begin{tabular}{|l|l|l|l|l|l|l|l|l|}
\hline $\mathrm{D}$ & 1 & 2 & 3 & 2 & 3 & 4 & 5 & 5 \\
\hline
\end{tabular}

Cluster $=$

\section{C1}

$\mu 1$

$$
=(1+2+3+2+3+4+5+5) / \text { total dataset Cluster }
$$


$\mu 1 \quad=3,125$

SSE $=$

$(1-3,125)^{2}+(2-3,125)^{2}+(3-3,125)^{2}+$

$(2-3,125)^{2}+(3-3,125)^{2}+(4-3,125)^{2}+$

$(5-3,125)^{2}+(5-3,125)^{2}$

SSE $=14,875$

b. Cluster 2

Pada tahapan selanjutnya dataset dibagikan menjadi 2 Cluster, pada pembagian Cluster dapat menggunakan metode K-Means. Data akan terus dibagikan menjadi beberapa clulster untuk mencari nilai SSE pada dataset, data tersebut akan memberikan informasi berupa grafik yang akan memberikan visual untuk mempermudah penentuan nilai $\mathrm{K}$ yang optimal.

Dataset $=$

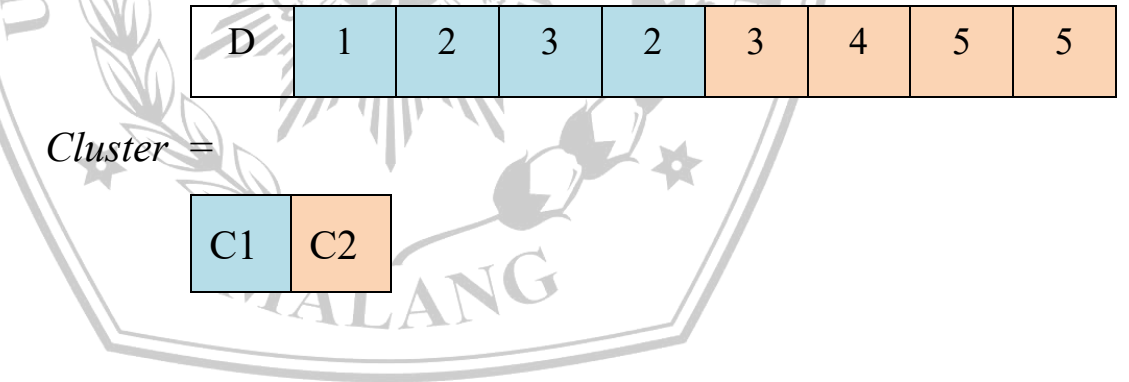

$$
\begin{array}{ll}
\mu 1 & =(1+2+3+2) / \text { total dataset Cluster } \\
& =8 / 4 \\
\mu 1 & =2 \\
\mu 2 & =(3+4+5+5) / \text { total dataset Cluster } \\
& =17 / 4 \\
\mu 2 & =4,25 \\
S S E & =
\end{array}
$$




$$
\begin{aligned}
& \left((1-2)^{2}+(2-2)^{2}+(3-2)^{2}+\right. \\
& \left.\left.(2-2)^{2}\right)\right)+\left((3-4,25)^{2}+(4-4,25)^{2}+\right. \\
& \left.(5-4,25)^{2}+(5-4,25)^{2}\right) \\
& \text { SSE } \quad=4,75
\end{aligned}
$$

c. Lakukan tahapan yang sama dengan jumlah clulster yang bertambah sampai dengan nilai $n$ Cluster yang telah ditentukan.

Nilai $S S E$ yang telah ditemukan akan berbentuk list dari tiap centroid, contohnya seperti di bawah :

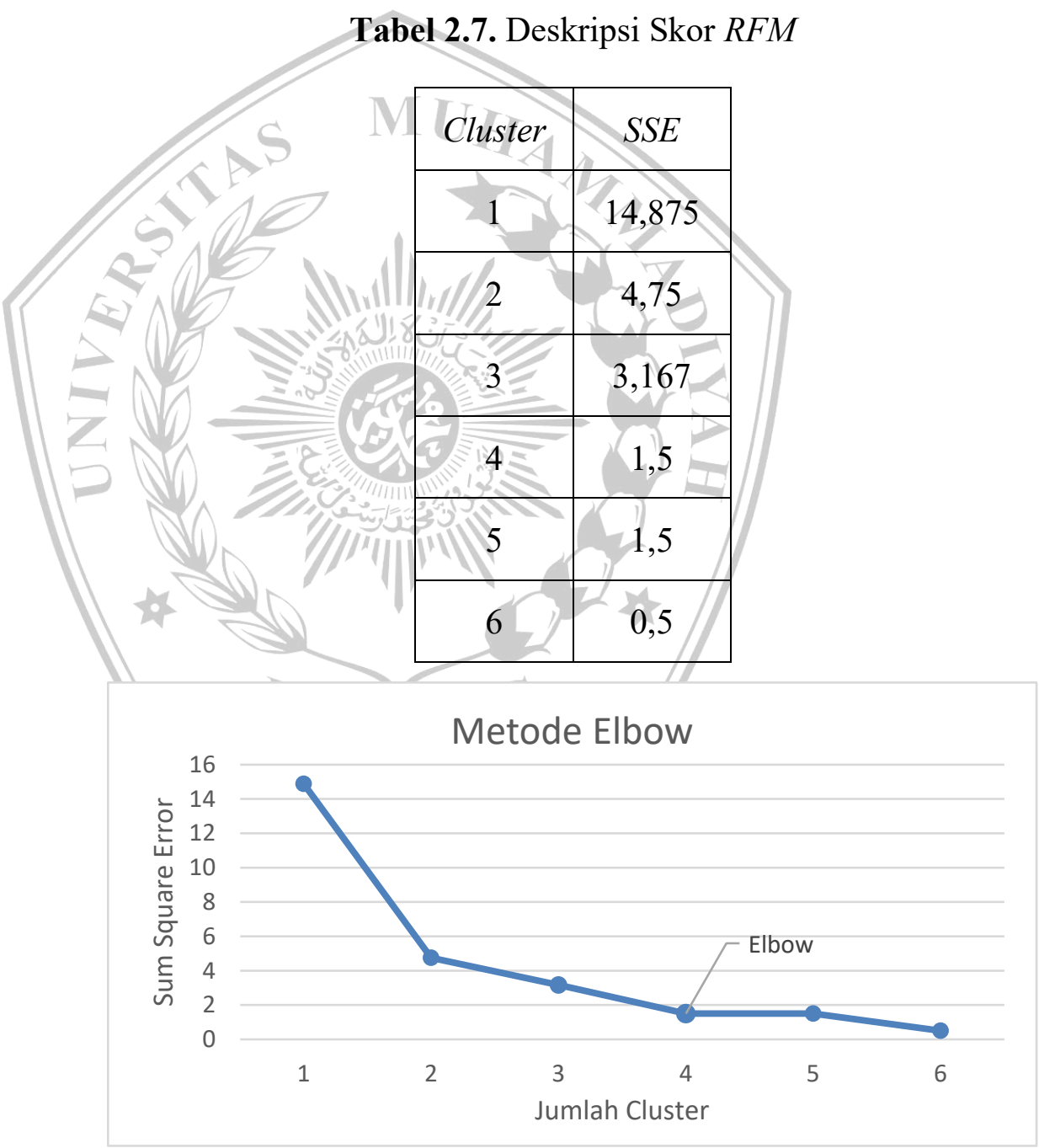

Gambar 2.1. Metode Elbow

Hasil dari grafik dapat dengan mudah dilihat pada perbedaan dari penurunan nilai SSE yang drastis pada Cluster 3, maka dari contoh tersebut dapat diambil kesimpulan bahwa nilai $\mathrm{k}=3$ merupakan nilai 
Cluster yang optimal [5].

\subsection{K-Means}

K-Means merupakan metode Clustering yang memiliki kinerja dalam mengelompokkan dasar data item dalam bentuk fitur yang baru pada grup K. Nilai K pada metode ini merupakan nilai ketentuan kelas yang akan terbentuk berdasarkan pada nilai yang di masukan pada nilai $\mathrm{K}$ itu sendiri. Penginputan nilai selalu dalam bentuk Integer yang positif $(1,2,3, \ldots)$. Pengelompokan pada metode $K$-Means akan dilakukan dengan cara mengurangi jumlah total kuadrat jarak antara Cluster centroid dan data [9]. Algoritma yang di terapkan pada K-Means seperti berikut [1] $[13][14][15]$

a. Menentukan Nilai K yang akan dibuat.

b. Menentukan Nilai K-Centroid secara acak.

c. Kalkulasikan jarak pada tiap data ke tiap Centroid. Kalkulasi tersebut dapat menggunakan jarak Euclidean ataupun jarak Manhattan dengan persamaan seperti berikut :

d. Euclidean

Euclidean merupakan perhitungan jarak dari sampel data yang berbeda. Hal ini dilakukan untuk menghitung Sum of Square dari semua koordinat yang sesuai.

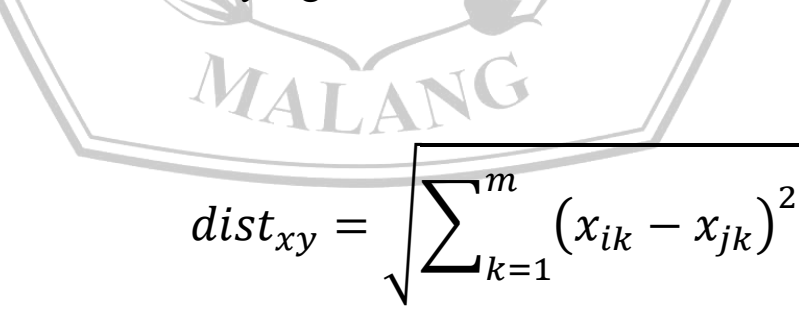

Keterangan :

dist $_{x y}=$ merupakan jarak antara Centroid $x_{j k}$ dengan data $x_{i k}$.

$x_{i k} \quad=$ merupakan data ke $i k$ dari dataset.

$x_{j k}=$ merupakan nilai Centroid $j k$ dari Cluster yang dipilih secara acak. 
e. Manhattan

Pada perhitungan Manhattan, untuk menghitung jarak dari tiap data, maka jarak dari titik Cluster dan tiap data di hitung menggunakan rumusnya seperti berikut :

$$
\operatorname{dist}_{x y}=\left|x_{i k}-x_{j k}\right|
$$

Keterangan :

dist $_{x y}=$ merupakan jarak antara Cluster $x_{j k}$ dengan data $x_{i k}$.

$x_{i k} \quad=$ merupakan data ke $i k$ dari dataset.

$x_{j k}=$ merupakan nilai Centroid $j k$ dari Cluster yang dipilih secara acak.

d. Data akan di kelompokan berdasarkan jarak terdekat antara data dan centroid

e. Pengulangan proses c dan d sampai keseluruhan objek tidak dapat diklasifikasikan lagi.

\subsubsection{Cara Kerja Metode K-Means Menggunakan Jarak Eucledian}

Berikut merupakan contoh dari penerapan/metode $K$-Means dengan jarak Euclidean.

a. $\quad$ Data set berupa 8 angka $=\{2,6,4,9,7,15,45,30\}$

b. Nilai $\mathrm{K}$ yang ditentukan yaitu $=2$

c. Iterasi pertama

1. Tentukan nilai centroid secara acak pada dataset

2. Dua centroid yang di pilih berupa angka $\{4\}$ dan $\{15\}$

3. Maka $\mathrm{C} 1=\{4\}, \mathrm{C} 2=\{15\}$

4. Menghitung jarak Euclidean pada dataset dan centroid

$$
D=[x, a]=\sqrt{(x-a)^{2}}
$$


Keterangan :

$D \quad=$ Adalah jarak antara centroid dan dataset

$x=$ Adalah nilai dari Centroid

$a \quad=$ Adalah nilai dari Dataset

Perhitungan :

$\mathrm{x}=2$

$\mathrm{a} 1=4$

$\mathrm{a} 2=15$

$\mathrm{D} 1 \mathrm{~S}=\sqrt{(2-4)^{2}} \quad$ D2 $=\sqrt{(2-15)^{2}}$

$=\sqrt{(-2)^{2}}=\sqrt{(-13)^{2}}$

$=\sqrt{4}$

$\mathrm{D} 2=13$

$\mathrm{D} 1=2$

Pada jarak Cluster yang terdekat atau terkecil pada keseluruhan Cluster akan ditetapkan sebagai kelompok Cluster data tersebut.

5. Hasil dari perhitungan jarak Euclidean

Tabel 2.8. Tabel Perhitungan Jarak

Euclidean Pertama

\begin{tabular}{|c|c|c|c|}
\hline Data Poin & D1 & D2 & Cluster \\
\hline 2 & 2 & 13 & $\mathrm{C} 1$ \\
\hline 6 & 2 & 9 & $\mathrm{C} 1$ \\
\hline 4 & 0 & 11 & $\mathrm{C} 1$ \\
\hline 9 & 5 & 6 & $\mathrm{C} 1$ \\
\hline 7 & 3 & 8 & $\mathrm{C} 1$ \\
\hline
\end{tabular}




\begin{tabular}{|c|c|c|c|}
\hline 15 & 11 & 0 & $\mathrm{C} 2$ \\
\hline 45 & 41 & 30 & $\mathrm{C} 2$ \\
\hline 30 & 26 & 15 & $\mathrm{C} 2$ \\
\hline
\end{tabular}

Keterangan :

D1 = Nilai terdekat Data poin dengan Cluster 1

D2 = Nilai terdekat Data poin dengan Cluster 2

Cluster $=$ Set Cluster sesuai dengan Data poin min / terdekat dari keseluruhan Cluster

6. Hasil Cluster Iterasi 1 yaitu

Cluster $1=\{2,6,4,9,7\}$

Cluster $2=\{15,45,30\}$

\section{d. Iterasi kedua}

1. Kalkulasi nilai Mean baru pada data poin dalam Cluster 1 dan 2

Mean 1 baru $=(2,6,4,9,7) / 5=5,6$

Mean 2 baru $=(15,45,30) / 3=30$

2. Menghitung jarak data poin dengan Cluster yang baru

3. Hasil perhitungan

Tabel 2.9. Tabel Perhitungan Jarak

Euclidean Kedua

\begin{tabular}{|c|c|c|c|}
\hline Data Poin & D1 & D2 & Cluster \\
\hline 2 & 3,6 & 28 & $\mathrm{C} 1$ \\
\hline 6 & 0,4 & 24 & $\mathrm{C} 1$ \\
\hline 4 & 1,6 & 26 & $\mathrm{C} 1$ \\
\hline
\end{tabular}




\begin{tabular}{|c|c|c|c|}
\hline 9 & 3,4 & 21 & $\mathrm{C} 1$ \\
\hline 7 & 1,4 & 23 & $\mathrm{C} 1$ \\
\hline 15 & 9,4 & 15 & $\mathrm{C} 1$ \\
\hline 45 & 39,4 & 15 & $\mathrm{C} 2$ \\
\hline 30 & 24,4 & 0 & $\mathrm{C} 2$ \\
\hline
\end{tabular}

4. Hasil yang diperoleh dari perhitungan sebelumnya menunjukkan bahwa data poin $\{15\}$ berganti ke Cluster 1

5. Hasil Cluster iterasi 2

Cluster $1=\{2,6,4,9,7,15\}$

Cluster $2=\{45,30\}$

\section{e. Iterasi ketiga}

1. Kalkulasi nilai Mean baru pada data poin dalam Cluster 1 dan 2

Mean 1 baru $=(2,6,4,9,7,15) / 6=7,16$

Mean 2 baru $=(45,30) / 2 \quad=37,5$

2. Menghitung jarak data poin dengan Cluster yang baru

3. Hasil perhitungan

Tabel 2.10. Tabel Perhitungan Jarak

Euclidean ketiga

\begin{tabular}{|c|c|c|c|}
\hline Data Poin & D1 & D2 & Cluster \\
\hline 2 & 5,16 & 35,5 & $\mathrm{C} 1$ \\
\hline 6 & 1,16 & 31,5 & $\mathrm{C} 1$ \\
\hline 4 & 3,16 & 33,5 & $\mathrm{C} 1$ \\
\hline 9 & 1,84 & 28,5 & $\mathrm{C} 1$ \\
\hline 7 & 0,16 & 30,5 & $\mathrm{C} 1$ \\
\hline
\end{tabular}




\begin{tabular}{|c|c|c|c|}
\hline 15 & 7,84 & 22,5 & $\mathrm{C} 1$ \\
\hline 45 & 37,84 & 7,5 & $\mathrm{C} 2$ \\
\hline 30 & 22,84 & 7,5 & $\mathrm{C} 2$ \\
\hline
\end{tabular}

4. Dapat dilihat bahwa perhitungan di iterasi ke 3 menunjukkan tidak ada perpindahan Cluster pada data poin dari iterasi sebelumnya,

5. Hasil Cluster iterasi 3

$$
\text { Cluster } 1=\{2,6,4,9,7,15\}
$$

Cluster $2=\{45,30\}$

Centroid $\mathrm{Cl} /=$

$$
(5.16+1.16+3.16+1.84+0.16+7.84) / 6=3.22
$$

$$
(35.5+31.5+33.5+28.5+30.5+22.5) / 6=30.33
$$

$$
=3.22,30.33
$$

\section{Centroid C2}

$(37,84+22,84) \backslash 2=30.34$

$(7,5+7,5) / 2 \quad=7.5$

$$
=30.34,7.5
$$

6. Pada Iterasi ke 3 dapat disimpulkan bahwa tahapan ini merupakan iterasi terakhir karna tidak terjadi perubahan Cluster pada data poin, maka hasil dari Cluster data set sebelumnya seperti berikut 


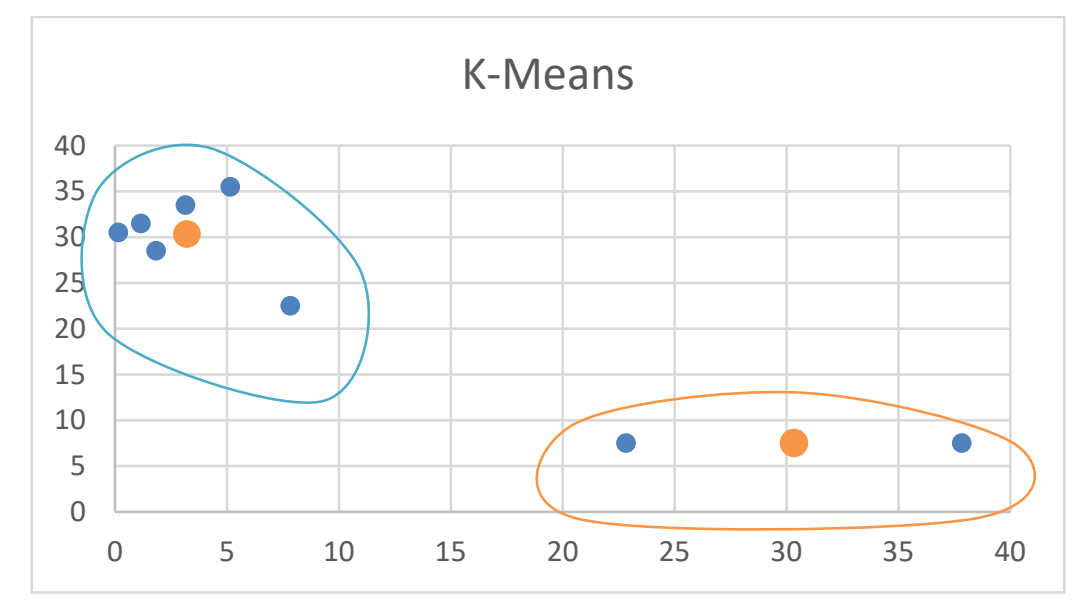

Gambar 2.2. Hasil dari penerapan metode $K$-Means menggunakan perhitungan jarak Eucledian.

\section{Keterangan :}

a. Dot berwarna Orange adalah Centroid masing-masing Cluster

b. Eingkaran berwarna Biru adalah Cluster 1

c. Lingkaran berwarna Orange adalah Cluster 2

\subsubsection{Cara Kerja Metode K-Means Menggunakan Jarak Manhattan}

Berikut merupakan/contoh dari penerapan metode K-Means dengan jarak Manhattan.

a. Data set berupa

$$
\text { Data } 1=\{2,6,4,9,7,15,45,30\}
$$

Data $2=\{5,7,3,6,9,13,50,60\}$

b. Nilai $\mathrm{K}$ yang ditentukan yaitu $=2$

\section{c. Iterasi pertama}

1. Tentukan nilai centroid secara acak pada dataset

2. Dua centroid yang di pilih berupa angka $\{4\}$ dan $\{15\}$

3. Maka $\mathrm{C} 1=\{4,3\}, \mathrm{C} 2=\{15,13\}$

4. Menghitung jarak Manhattan pada dataset dan centroid

$$
D=|a-x|
$$


Keterangan :

$D \quad=$ Adalah jarak antara centroid dan dataset

$x \quad=$ Adalah nilai dari Centroid

$a \quad=$ Adalah nilai dari Dataset

Perhitungan :

$x 1=2 \quad x 2=5$

$\mathrm{a} 1=4 \quad \mathrm{a} 2=15$

D1 $=|2-4|+|5-3|$

$|-2|+|2|$

$=2+2$

D1 $=4$

D2 $=|2-15|+|5-13|$

$\Sigma=|-13|+|-8|$

$$
=13+8
$$

D2

$$
=21
$$

Pada jarak Cluster yang terdekat atau terkecil pada keseluruhan Cluster akan ditetapkan sebagai kelompok Cluster data tersebut.

5. Hasil dari perhitungan jarak Cosine

Tabel 2.11. Tabel Perhitungan Jarak Cosine Pertama

\begin{tabular}{|c|c|c|c|c|}
\hline Data Poin 1 & Data Poin 2 & D1 & D2 & Cluster \\
\hline 2 & 5 & 4 & 21 & $\mathrm{C} 1$ \\
\hline 6 & 7 & 6 & 15 & $\mathrm{C} 1$ \\
\hline 4 & 3 & 0 & 21 & $\mathrm{C} 1$ \\
\hline
\end{tabular}




\begin{tabular}{|c|c|c|c|c|}
\hline 9 & 6 & 8 & 13 & $\mathrm{C} 1$ \\
\hline 7 & 9 & 9 & 12 & $\mathrm{C} 1$ \\
\hline 15 & 13 & 21 & 0 & $\mathrm{C} 2$ \\
\hline 45 & 50 & 88 & 67 & $\mathrm{C} 2$ \\
\hline 30 & 60 & 83 & 62 & $\mathrm{C} 2$ \\
\hline
\end{tabular}

Keterangan :

D1 = Nilai terdekat Data poin dengan Cluster 1

D2 = Nilai terdekat Data poin dengan Cluster 2

Cluster $=$ Set Cluster sesuai dengan Data poin min / terdekat dari keseluruhan Cluster

6. Hasil Cluster Iterasi 1 yaitu

Cluster $1=\{2,6,4,9,7\},\{5,7,3,6,9\}$

Cluster $2=\{15,45,30\},\{50,60\}$

\section{d. Iterasi kedua}

1. Kalkulasi nilai Mean baru pada data poin dalam Cluster 1 dan 2

Mean 1 baru $=(2,6,4,9,7) / 5,(5,7,3,6,9) / 5=5.6,6$

Mean 2 baru $=(15,45,30) / 3,(50,60) / 5=30,41$

2. Menghitung jarak data poin dengan Cluster yang baru

3. Hasil perhitungan

Tabel 2.12. Tabel Perhitungan Jarak Euclidean Kedua

\begin{tabular}{|c|c|c|c|c|}
\hline Data Poin 1 & Data Poin 2 & D1 & D2 & Cluster \\
\hline 2 & 5 & 5 & 64 & $\mathrm{C} 1$ \\
\hline 6 & 7 & 1 & 58 & $\mathrm{C} 1$ \\
\hline 4 & 3 & 5 & 64 & $\mathrm{C} 1$ \\
\hline
\end{tabular}




\begin{tabular}{|c|c|c|c|c|}
\hline 9 & 6 & 3 & 56 & $\mathrm{C} 1$ \\
\hline 7 & 9 & 4 & 55 & $\mathrm{C} 1$ \\
\hline 15 & 13 & 16 & 43 & $\mathrm{C} 1$ \\
\hline 45 & 50 & 83 & 24 & $\mathrm{C} 2$ \\
\hline 30 & 60 & 78 & 19 & $\mathrm{C} 2$ \\
\hline
\end{tabular}

4. Hasil yang diperoleh dari perhitungan sebelumnya menunjukkan bahwa data poin $\{15\},\{13\}$ berganti ke Cluster 1

5. Hasil Cluster iterasi 2

Cluster $1=\{2,6,4,9,7,15\},\{5,7,3,6,9,13\}$

Cluster $2=\{45,30\},\{50,60\}$

\section{e. Iterasi ketiga}

1. Kalkulasi nilai Mean baru pada data poin dalam Cluster 1 dan 2

Mean I baru

$(2,6,4,9,7,15) / 6,(5,7,3,6,9,13) / 6$

Mean 2 baru

$(45,30) / 2,(50,60) / 2$

$$
=37.5,55
$$

2. Menghitung jarak data poin dengan Cluster yang baru

3. Hasil perhitungan

Tabel 2.13. Tabel Perhitungan Jarak Euclidean ketiga

\begin{tabular}{|c|c|c|c|c|}
\hline Data Poin 1 & Data Poin 2 & D1 & D2 & Cluster \\
\hline 2 & 5 & 7 & 86 & C1 \\
\hline 6 & 7 & 1 & 80 & C1 \\
\hline
\end{tabular}




\begin{tabular}{|c|c|c|c|c|}
\hline 4 & 3 & 7 & 86 & $\mathrm{C} 1$ \\
\hline 9 & 6 & 3 & 78 & $\mathrm{C} 1$ \\
\hline 7 & 9 & 2 & 77 & $\mathrm{C} 1$ \\
\hline 15 & 13 & 14 & 65 & $\mathrm{C} 1$ \\
\hline 45 & 50 & 81 & 13 & $\mathrm{C} 2$ \\
\hline 30 & 60 & 76 & 13 & $\mathrm{C} 2$ \\
\hline
\end{tabular}

4. Dapat dilihat bahwa perhitungan di iterasi ke 3 menunjukkan tidak ada perpindahan Cluster pada data poin dari iterasi sebelumnya,

5. Hasil Cluster iterasi 3

Cluster $1=\{2,6,4,9,7,15\},\{5,7,3,6,9,13\}$

Cluster $2=\{45,30\},\{50,60\}$

Centroid C1

$(7+1+7+3+2+14)+6 \quad D=5.66$

$(86+80+86+78+77+65) / 6=78,66$

$=5.66,78.66$

Centroid C2

$(81+76) / 2=78.5$

$(13+13) / 2=13$

$=78.5,13$

Pada Iterasi ke 3 dapat disimpulkan bahwa tahapan ini merupakan iterasi terakhir karna tidak terjadi perubahan Cluster pada data poin, maka hasil dari Cluster data set sebelumnya seperti berikut 


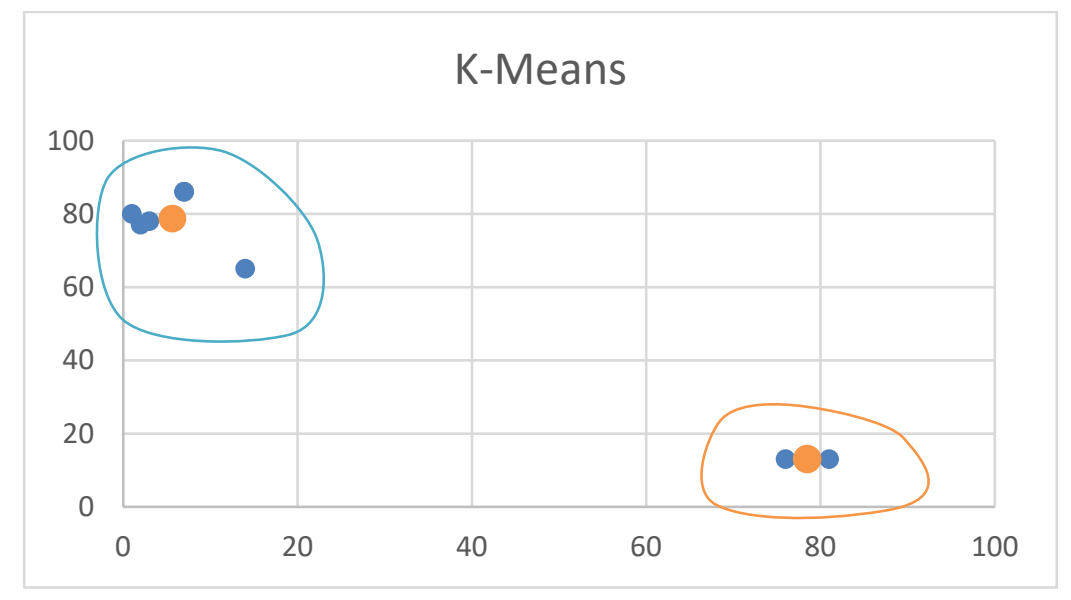

Gambar 2.3. Hasil dari penerapan metode K-Means menggunakan perhitungan jarak Manhattan.

\section{Keterangan: \\ a. Dot berwarna oranye adalah Centroid masing-masing Cluster \\ b. Lingkaran berwarna Biru adalah Cluster 1, Lingkaran berwarna oranye adalah Cluster 2}

\subsection{Silhouette Coefficient}

Metode Silhoutte Coefficient memiliki kinerja dalam melihat kualitas dan kekuatan pada Cluster yang dibentuk. Data yang ditempatkan pada suatu Cluster dapat diketahui seberapa baik penempatannya. Dalam menerapkan metode ini terdiri dari 3(tiga) tahapan, yaitu [16] :

1. Menghitung nilai rata-rata pada jarak dari suatu data $i$ dengan data lain yang berada pada Cluster yang sama.

$$
a(i)=\frac{1}{|A|-1} \sum j \in_{a, j \neq i} d(i, j)
$$

Nilai $i$ merupakan data dari cluster $A$ dan $j$ data lain yang berada pada cluster yang sama, nilai $d(i, j)$ merupakan jarak antara dokumen $i$ dengan $j$. Dalam perhitungan jarak dapat menggunakan algoritma seperti Euclidean, Manhattan, dll.

2. Tahapan kedua yaitu menghitung nilai rata-rata jarak dari suatu data $i$ dengan 
semua data $j$ yang berada pada Cluster lain dan akan di ambil nilai terkecilnya.

$$
d(i, C)=\frac{1}{|A|} \sum j \in C d(i, j)
$$

Dimana nilai $d(i, C)$ merupakan jarak rata-rata data $i$ dengan semua data pada Cluster lain $C$ dimana $A \neq C$.

$$
b(i)=\min C \neq A d(i, C)
$$

3. Bila nilai $a(i)$ dan $b(i)$ telah ditemukan maka untuk memperoleh nilai Silhoutte Coefficient menggunakan rumus seperti berikut.

$$
s(i)=\frac{\bigcup b(i)-a(i)}{\max (a(i), b(i))}
$$

\subsubsection{Cara Kerja Metode Silhoutte Coefficient}

Sebelum diterapkan metode Silhoutte Coefficient, maka dibentuk terlebih dahulu kelompok-kelompok data (Cluster) yang berada pada data mentah. Berikut merupakan contoh data yang telah dibentuk dan dikelompokkan pada tiap Cluster.

Tabel 2.14. Hasil Clustering Manhattan Distance

\begin{tabular}{|c|c|c|c|}
\hline No. & Data 1 & Data 2 & Cluster \\
\hline 1 & A 2 & 5 & $\mathrm{C} 1$ \\
\hline 2 & 6 & 7 & $\mathrm{C} 1$ \\
\hline 3 & 4 & 3 & $\mathrm{C} 1$ \\
\hline 4 & 9 & 6 & $\mathrm{C} 1$ \\
\hline 5 & 7 & 9 & $\mathrm{C} 1$ \\
\hline 6 & 15 & 13 & $\mathrm{C} 1$ \\
\hline 7 & 45 & 50 & $\mathrm{C} 2$ \\
\hline 8 & 30 & 60 & $\mathrm{C} 2$ \\
\hline
\end{tabular}

Pada contoh data di atas merupakan hasil dari perhitungan jarak menggunakan 
algoritma Manhattan Distance. Berikut merupakan tahapan pertama dalam menerapkan metode Silhoutte Coefficient, yaitu mencari nilai $a(i)$.

1. Mencari nilai rata-rata jarak pada data i dengan data lain pada Cluster yang sama. Pada perhitungan ini maka dimulai dengan Cluster 1 terlebih dahulu untuk mencari nilai $s(i)$ nya.

$$
a(i)=\frac{1}{|A|-1} \sum j \in_{a, j \neq i} d(i, j)
$$

Dalam mencari nilai rata-rata jarak maka tentukan terlebih dahulu algoritma yang akan digunakan dalam menentukan nilai jarak antar data. Dikarenakan pada contoh data yang dipakai merupakan hasil dari perhitungan menggunakan algoritma Manhattan Distance maka pada perhitungan nilai $a(i)$ akan menggunakan algoritma yang sama. Maka nilai $d(i, j)$ dihitung dengan cara seperti berikut.

$$
\left|\operatorname{dist}_{x y}=\right| x_{i k}-x_{j k} \mid
$$

Data i (1) $=(2,5)$

Dataj $=(2,5),(6,7),(4,3),(9,6),(7,9),(15,13)$

$\mathrm{a}(1)$

$$
=|2-5|,|2| \pi|,| 2-4|,| 2-9|,| 2-7|,| 2-15 \mid
$$

$$
=(0,4,2,7,5,13)
$$$$
=|5-5|,|5-7|,|5-3|,|5-6|,|5-9|,|5-13|
$$$$
=(0,2,2,1,4,8)
$$

$$
=(0+0,4+2,2+2,7+1,5+4,13+8)
$$$$
=0,6,4,8,9,21
$$$$
=(0+6+4+8+9+21) / 6
$$

$\mathrm{a}(1)$

$$
=8
$$

Perhitungan akan terus berlanjut sampai keseluruhan tiap-tiap data Cluster telah dikalkulasikan rata-rata jarak antar data lainya. Maka hasilnya seperti tabel berikut.

Tabel 2.15. Hasil Kalkulasi Nilai a(i) 


\begin{tabular}{|c|c|c|c|c|}
\hline No. & Data 1 & Data 2 & Cluster & $\mathrm{a}(\mathrm{i})$ \\
\hline 1 & 2 & 5 & $\mathrm{C} 1$ & 8.000000 \\
\hline 2 & 6 & 7 & $\mathrm{C} 1$ & 5.666667 \\
\hline 3 & 4 & 3 & $\mathrm{C} 1$ & 8.000000 \\
\hline 4 & 9 & 6 & $\mathrm{C} 1$ & 6.333333 \\
\hline 5 & 7 & 9 & $\mathrm{C} 1$ & 6.333333 \\
\hline 6 & 15 & 13 & $\mathrm{C} 1$ & 13.666667 \\
\hline 7 & 45 & 50 & $\mathrm{C} 2$ & 12.5 \\
\hline 8 & 30 & 60 & $\mathrm{C} 2$ & 12.5 \\
\hline
\end{tabular}

2. Pada tahapan selanjutnya tiap data $\mathrm{i}$ akan dikalkulasikan rata-rata jaraknya dengan keseluruhan data $j$ pada Cluster lain. Dalam perhitungan rata-rata jaraknya sama seperti sebelumnya akan tetapi jarak data j merupakan data dari Cluster yang berbeda atau tidak sama dengan Cluster dari data i. Berikut merupakan tahapan kalkulasi mencari nilai $d(i, j)$

$$
\begin{aligned}
& d(i, C)=\frac{1}{|A|} \sum j \in C d(i, j) \\
& b(i)=\min C \neq A d(i, C)
\end{aligned}
$$

Data $\mathrm{i}(1)=(2,5)$

Data j $\mathrm{C} 2=(45,50),(30,60)$

$\mathrm{b}(1) \quad=|2-45|,|2-30|$

$=(43,28)$

$=|5-50|,|5-60|$

$=(45,55)$

$=(43+45,28+55)$

$=88,83$

$=(88+83) / 2$ 
$b(1)$ $=85.5$

Setelah keseluruhan data i telah ditemukan nilai $d(i, C)$ maka akan dibandingkan nilai terkecilnya menggunakan rumus $b(i)$. Setiap data i yang telah dikalkulasi nilainya dengan data $\mathrm{j}$ pada Cluster lain akan menghasilkan hasil berupa kalkulasi lebih dari satu Cluster $(1,2),(1,3)$... $(1, \mathrm{C})$. Hasil dari kalkulasi beberapa Cluster tersebut akan dipilih nilai min dari jumlah Cluster yang ada, dikarenakan pada contoh ini hanya terdiri dari 2 Cluster maka nilai $d(i, 2)$ merupakan nilai yang dipilih sebagai nilai $b(i)$. Berikut adalah hasil analisa pada perhitungan jarak data i dengan data pada Cluster 2.

Tabel 2.16. Hasil Kalkulasi Nilai d(i,C) \& b(i)

\begin{tabular}{|c|c|c|c|c|c|c|}
\hline No. & Data 1 & Data 2 & Cluster & a(i) & $\mathrm{d}(\mathrm{i}, 2)$ & b(i) \\
\hline & & 5 & & 00000 & 85.5 & 85.5 \\
\hline & 6 & 7 & & & 79.5 & 79.5 \\
\hline & & & & 8.000000 & 85.5 & 85.5 \\
\hline-4 & & & $\mathrm{C} 1$ & 6.333333 & 77.5 & 77.5 \\
\hline 5 & & 9 & $\mathrm{C} 1$ & 6.333333 & 76.5 & 76.5 \\
\hline 6 & 15 & & $\mathrm{Cl}$ & 13.666667 & 64.5 & 64.5 \\
\hline 7 & 45 & 50 & $\mathrm{C} 2$ & 12.5 & 80.666667 & 80.666667 \\
\hline 8 & 30 & 60 & $\mathrm{C} 2$ & 12.5 & 75.666667 & 75.666667 \\
\hline
\end{tabular}

3. Tahapan terakhir yaitu menghitung nilai $s(i)$ yang merupakan nilai dari Silhoutte Coefficient, dalam menghitung nilai $s(i)$ maka algoritma yang diperlukan berupa

$$
s(i)=\frac{b(i)-a(i)}{\max (a(i), b(i))}
$$

Nilai dari $b(i)$ akan di kurangi dengan nilai $a(i)$, dan akan dibagikan dengan nilai tertinggi antara kedua data tersebut. Maka untuk memperoleh nilai s(i) caranya seperti berikut :

$\mathrm{a}(1)=8$ 
$\mathrm{b}(1) \quad=85.5$

$\mathrm{s}(1)$

$$
\begin{aligned}
& =\frac{85.5-8}{\max (85.5,8)} \\
& =\frac{85.5-8}{85.5} \\
& =\frac{77.5}{85.5}
\end{aligned}
$$

$\mathrm{s}(1) \quad=0.906433$

Data a(i) dan b(i) akan dikalkulasikan secara keseluruhan untuk mendapat nilai s(i) dari semua data pada tiap Cluster. Berikut merupakan hasil keseluruhan dari kalkulasi nilai s(i).

Tabel 2.17. Hasil Kalkulasi Nilai s(i)

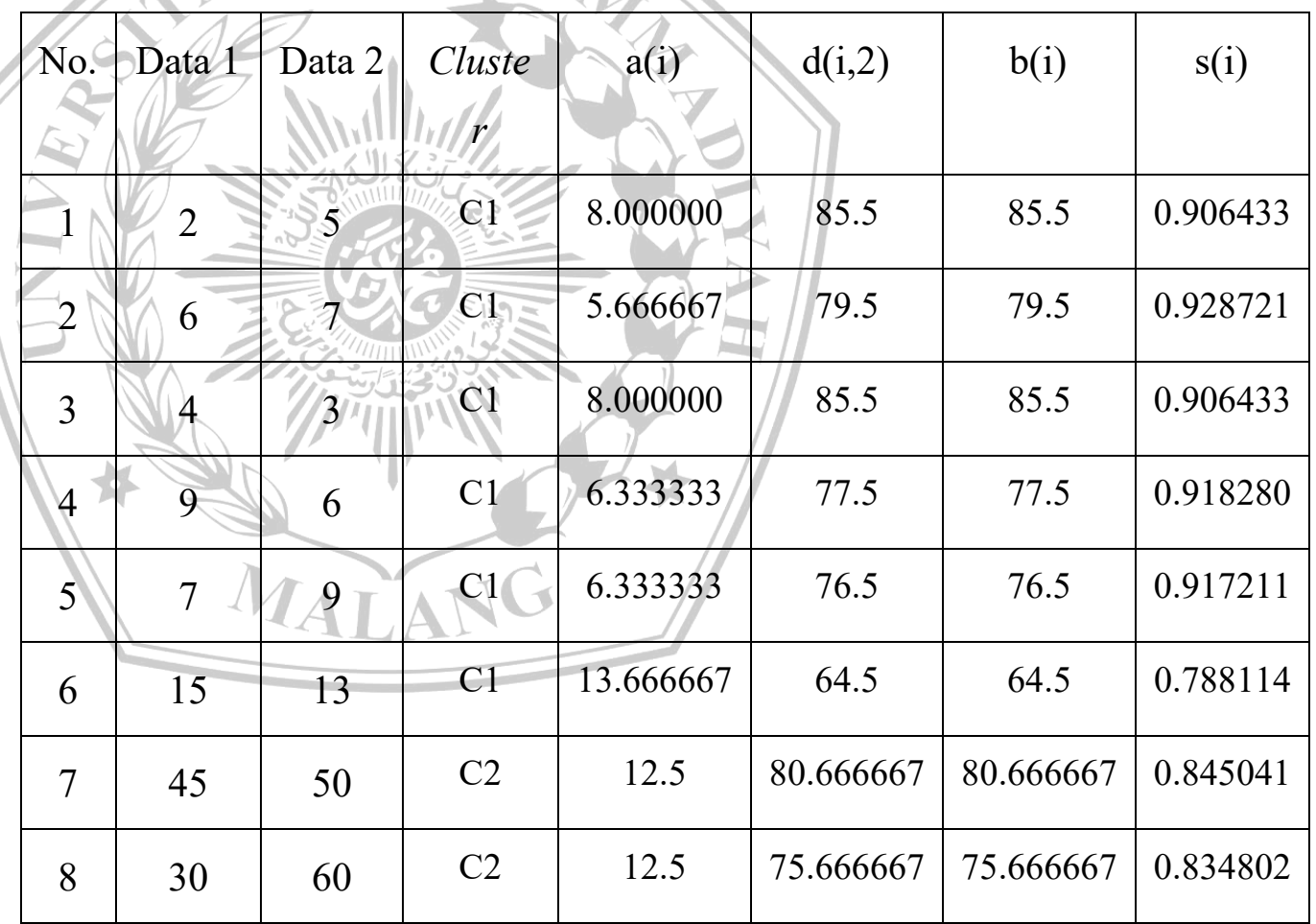

Dengan hasil dari nilai s(i) yang telah diperoleh maka nilai Silhoutte Coefficient telah didapat. Pada nilai s(i) untuk menentukan kualitas dari Cluster yang dibentuk yaitu dengan skala +1 sampai -1 . Bila nilai s(i) mendekati nilai 1 atau lebih maka Cluster yang dibuat tergolong berkualitas, begitu juga terbalik dengan nilai yang mendekati -1 [17]. Dengan memanfaatkan metode silhoutte coefficient, maka tak hanya dapat menentukan kualitas suatu cluster yang dibentuk, akan tetapi saat nilai s(i) dari keseluruhan cluster diambil nilai rata- 
ratanya maka dapat memperoleh nilai kualitas suatu algoritma dalam mengelompokkan data.

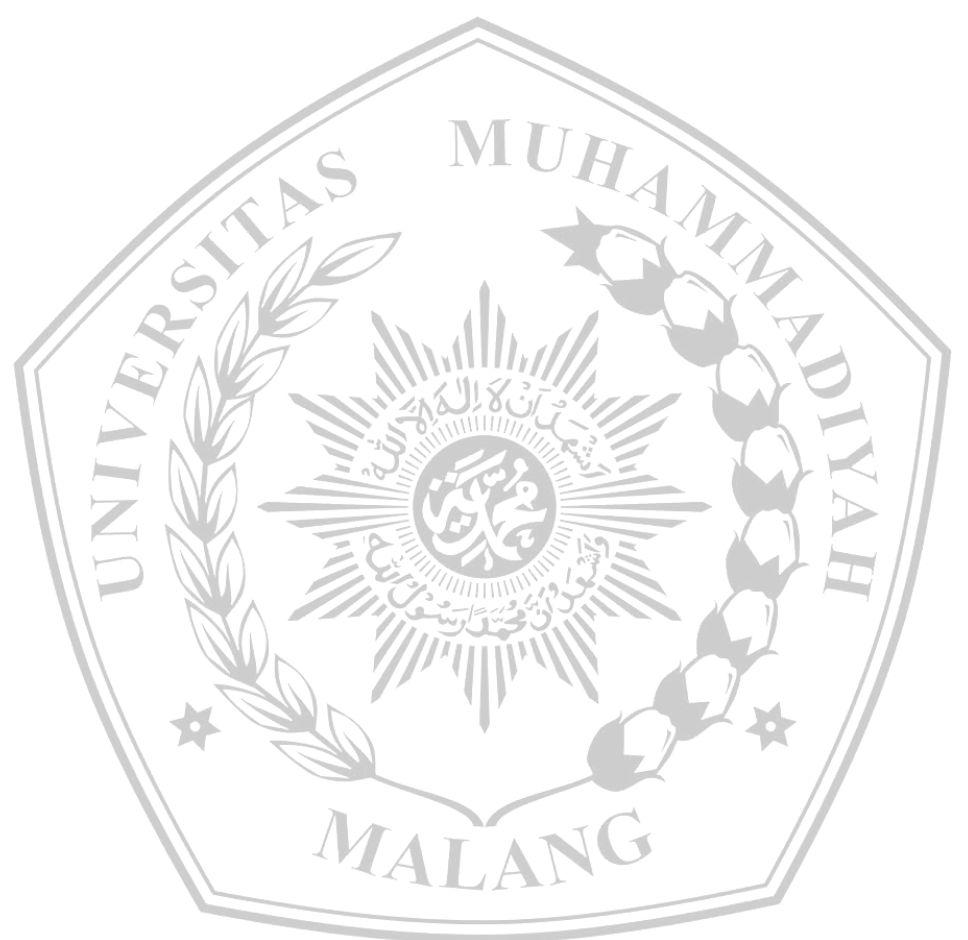

